\title{
UNDETECTED HEPATITIS-C VIRUS INFECTION IN HAEMODIALYSIS PATIENTS: IMPORTANCE OF PCR HCV RNA AND ELIZA METHOD
}

\author{
YASIR HUSSAIN ${ }^{1}$, ROSHINA ANJUM ${ }^{1}$, NAZISH MUNAWAR ${ }^{1}$, ZAHRA FATIMA $^{2}$, SABA NAZ $^{3}$, \\ ADIL MEHMOOD ${ }^{4}$ \\ ${ }^{1}$ Department of Nephrology, Lahore General Hospital, Pharmacist, Lahore General Hospital, ${ }^{2}$ PGR (Medicine), \\ JPMC Karachi, ${ }^{3} \mathrm{MO}, \mathrm{DHQ}$ Sheikhupura, ${ }^{4}$ Department of Medicine, BVH, Bahawalpur
}

\begin{abstract}
Background: Haemodialysis (HD) is one of the most common type of renal replacement therapy (RRT) used for end stage kidney disease (ESKD). Hepatitis-C is the most frequent infection in haemodialysis. Early detection of this viral infection can lead to early treatment, lesser morbidity and mortality. PCR test is being used instead of Elisa in centres where HCV infection is more prevalent as PCR for HCV RNA is considered more reliable than Eliza in haemodialysis patients.

Objective: To assess the accuracy of Eliza and PCR method for the detection of Hepatitis-C viral infection in haemodialysis patients.

Methods: A cross sectional study was conducted at Dialysis Centre of DHQ hospital Sheikhupura, Punjab, Pakistan in January 2018. All patients who were on maintenance haemodialysis for more than six months were included in the study. Patients with acute kidney disease and on dialysis less than six months were excluded. All patients were tested by enzymes linked immune-sorbent essay (ELIZA) and polymerase chain reaction (PCR) method for HCV status.

Results: Out of 152 haemodialysis patients tested, $94(61.84 \%)$ cases were positive by both ELIZA and PCR methods while 6 (3.94\%) cases with negative ELIZA were PCR positive. Number of dialysis, blood transfusions and serology were important risk factors with significant $\mathrm{p}$ value. $(<0.05)$

Conclusion: In centres where Hepatitis-C is more prevalent, PCR for HCV RNA should be preferred over ELIZA method for early detection of HCV viral infection.
\end{abstract}

Keywords: Hepatitis-C, haemodialysis, nephrologist, PCR.

How to cite this article: Hussain Y, Anjum R, Munawar N, Fatima Z, Naz S, Mehmood A. Undetected Hepatitis-C virus infection in haemodialysis patients: Importance of PCR HCV RNA and Eliza method. Pak Postgrad Med J 2020;31(4): 182-185

This is an Open Access article distributed under the terms of the Creative Commons Attribution License (http://creativecommons.org/licenses/by/3.0), which permits unrestricted use, distribution, and reproduction in any medium, provided the original work is properly cited.

DOI: http://doi.org/10.51642/ppmj.v31i04.402

Correspondence to: Roshina Anjum,

Assistant Professor,

Department of Nephrology, Lahore General Hospital, Lahore, Pakistan.

Email:write2drroshina@gmail.com

\section{INTRODUCTION}

End stage renal disease is a major health problem in Pakistan and the burden of disease is increasing with every passing day ${ }^{1}$.About 71.1 million people in world are infected with hepatitis $C^{2}$. Due to its major effects on mortality and morbidity it is an issue of global concern now ${ }^{3-7}$. Among hepatitis c untreated patients, a major number develop cirrhosis while few of them develop hepatocellular carcinoma ${ }^{8}$. Every $20^{\text {th }}$ Pakistani has been exposed to hepatitis c infection with an overall prevalence of $5 \%$ with a major role of healthcare workers in its transmission ${ }^{9}$.

Hepatitis $\mathrm{c}$ is very common in dialysis patients due to many reasons like poor implication of infection control strategies in dialysis centres ${ }^{10}$, poor screening in blood banks before transfusion, repetitive intravenous interventions and immunocompromised status of patients ${ }^{11}$.According to a recent study done in Pakistan, prevalence of hepatitis c among haemodialysis patients ranges from $16.4 \%$ to $68.0 \%$ which is significantly higher than general population i.e. $5 \%{ }^{9}$. Chronic liver disease (CLD) is of one of the top three causes of mortality in ESRD patients and hepatitis $\mathrm{c}$ is one of the most important causes of CLD.

Accurate and in time diagnosis will help in reducing mortality rate in ESRD patients and will reduce the horizontal transmission of virus in dialysis centres as well $^{12-13}$. Commonly used diagnostic tests for detection 
of hepatitis $\mathrm{C}$ are measurement of antibody level by ELIZA or PCR for viral RNA.

Antibodies take some time to develop after infection i-e window period or may not develop to same level in immunocompromised conditions like dialysis ${ }^{14}$, making ELIZA less reliable to diagnose a patient with active infection of hepatitis $\mathrm{C}^{15}$. It has been studied in some parts of the world but no local data is available so the rationale of our study is to find out the most accurate method of diagnosing hepatitis $\mathrm{c}$ in ESRD patients of our population to ensure early diagnosis and treatment.

\section{METHODS}

A cross sectional study was conducted at Dialysis centre of DHQ hospital, Sheikhupura, Punjab, Pakistan in January 2018. All the patients who were on haemodialysis for more than six months were included in the study. A total of 152 patients, from 16 to 75 years old patients were in our study. Patients with Acute kidney injury (AKI), patients with ESKD who came to centre for short time period (less than six months) and Patients with age $<15$ or $>75$ were excluded from study. All patients were on maintenance dialysis, two sessions a week, each session of four hours. There was no isolation for $\mathrm{HCV}$ positive or negative patients. Dedicated machines were reserved for seropositive patients on same floor, where area was separated by a small brick wall. One dialyzer was being reused three times for dialysis and then discarded. Chemical disinfection of dialyzer was done after each dialysis. All patients fulfilling the study criteria were enrolled in the study. Demographic data of the patient's (age, gender, occupation and marital state) was collected by direct interview. Viral status, duration on HD, history of blood transfusion(s), attending more than one HD centre and type of vascular access for HD (arterio-venous fistula, double lumen catheter, permanent catheter) number of blood transfusions per month was taken from record and noted in preformed Performa. Blood samples were collected pre-dialysis. Four millilitres $(\mathrm{ml})$ of blood for ELIZA and six millilitres $(\mathrm{ml})$ of blood for PCR in separate serum vial were stored. All samples were centrifuged and then frozen in the centre before sending to laboratory for third generation ELIZA and real time PCR for HCV.

\section{RESULTS}

Table I shows the baseline characteristics of the studied population. Results showed $51.1 \%$ males were more than 50 -years old, and $59.8 \%$ females were more than 50 -years old, $36.1 \%$ males and $51.5 \%$ female were illiterate, $65.4 \%$ male and $96.9 \%$ females were unemployed, $60.2 \%$ male and $42.3 \%$ female were rural. Out of 152 haemodialysis patients 94 (61.84\%) cases were positive by both ELIZA and PCR methods while $6(3.94 \%)$ cases were negative by ELIZA but positive by PCR.

Table II gives the results of PCR association with clinical parameters. It was observed that total number of dialysis and blood transfusion required had significant association with PCR. 56\% PCR positive cases had more than 100 number of dialysis and $6 \%$ had more than 4-times blood transfusion per month. 94 cases were PCR positive with positive serology and 19 cases were found PCR negative with negative serology as shown in figure 1 .

Figure 1:

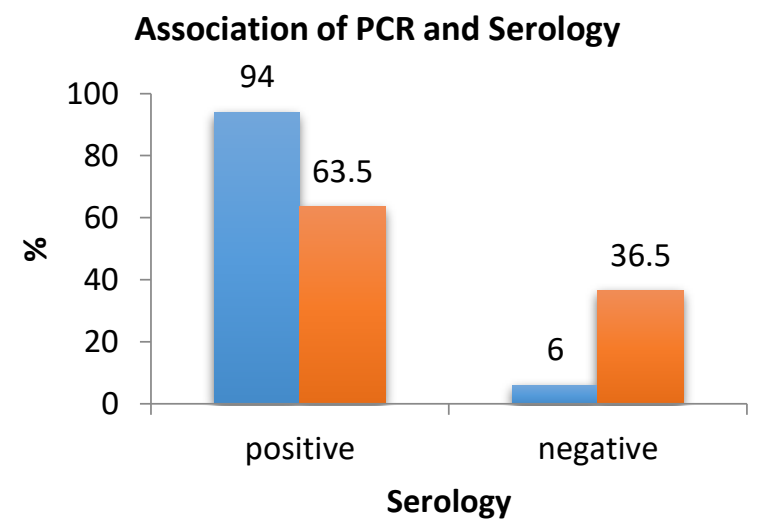

PCR positive $\quad$ PCR negative

Table I: Baseline Characteristics of Studied Samples $(n=152)$

\begin{tabular}{|c|c|c|c|c|c|}
\hline \multirow{2}{*}{\multicolumn{2}{|c|}{ Characteristics }} & \multicolumn{4}{|c|}{ Gender } \\
\hline & & \multicolumn{2}{|c|}{ Male $(n=88)$} & \multicolumn{2}{|c|}{ Female $(n=64)$} \\
\hline & & $\mathrm{N}$ & $\%$ & $\mathrm{~N}$ & $\%$ \\
\hline \multirow{3}{*}{ Age group } & $16-30$ & 11 & 12.5 & 09 & 14.1 \\
\hline & $30-50$ & 32 & 36.3 & 17 & 26.6 \\
\hline & $>50$ & 45 & 51.2 & 38 & 59.3 \\
\hline \multirow[t]{2}{*}{ Education } & Literate & 56 & 63.6 & 31 & 48.4 \\
\hline & Illiterate & 32 & 36.4 & 33 & 51.6 \\
\hline \multirow[t]{2}{*}{ Employment status } & Employed & 30 & 34.0 & 02 & 3.1 \\
\hline & Unemployed & 58 & 66.0 & 62 & 96.9 \\
\hline \multirow[t]{2}{*}{ Address } & Urban & 35 & 39.8 & 37 & 57.8 \\
\hline & Rural & 53 & 60.2 & 27 & 42.2 \\
\hline
\end{tabular}


Table II: Association of PCR with Clinical Variables

\begin{tabular}{|c|c|c|c|c|c|c|}
\hline \multirow{2}{*}{\multicolumn{2}{|c|}{ Clinical Variables }} & \multicolumn{2}{|c|}{ Positive $(n=100)$} & \multicolumn{2}{|c|}{ Negative $(n=52)$} & \multirow{2}{*}{$\mathrm{P}$ value } \\
\hline & & $\mathrm{N}$ & $\%$ & $\mathrm{n}$ & $\%$ & \\
\hline \multirow[t]{7}{*}{ Cause of ESKD } & $\mathrm{DM}$ & 12 & 12.0 & 1 & 1.9 & \multirow{7}{*}{0.45} \\
\hline & HTN & 38 & 38.0 & 22 & 42.3 & \\
\hline & Stone disease & 2 & 2.0 & 1 & 1.9 & \\
\hline & chronic GN & 6 & 6.0 & 1 & 1.9 & \\
\hline & cystic disease & 2 & 2.0 & 2 & 3.8 & \\
\hline & both DM and HTN & 37 & 37.0 & 23 & 44.2 & \\
\hline & Other & 3 & 3.0 & 2 & 3.8 & \\
\hline \multirow[t]{2}{*}{ Dialysis starts via } & AVF & 22 & 22.0 & 6 & 11.5 & \multirow{2}{*}{0.10} \\
\hline & double lumen catheter & 78 & 78.0 & 46 & 88.5 & \\
\hline \multirow{3}{*}{$\begin{array}{l}\text { Total number of } \\
\text { dialysis }\end{array}$} & $<50$ & 12 & 12.0 & 16 & 30.8 & \multirow{3}{*}{$0.006^{*}$} \\
\hline & $50-100$ & 32 & 32.0 & 12 & 23.1 & \\
\hline & $>100$ & 56 & 56.0 & 24 & 46.2 & \\
\hline \multirow[t]{2}{*}{ need for transfusion } & Yes & 79 & 79.0 & 35 & 67.3 & \multirow{2}{*}{0.28} \\
\hline & No & 21 & 21.0 & 17 & 32.7 & \\
\hline \multirow{2}{*}{$\begin{array}{l}\text { blood transfusion } \\
\text { required }\end{array}$} & $<2$ times per month & 67 & 67.0 & 24 & 46.2 & \multirow{2}{*}{$<0.01 *$} \\
\hline & 2-4 times per month & 27 & 27.0 & 15 & 28.8 & \\
\hline
\end{tabular}

\section{DISCUSSION}

Hepatitis $\mathrm{C}$ in Pakistan is common in general population. And is even more common in CKD due to multiple risk factors like frequent hospitalizations and need of repetitive blood transfusions. Which ultimately contributes to increased frequency of hepatitis $c$ in end stage renal disease patients on haemodialysis ,ranging from $23.7 \%-56.6 \%$ 10,16-17.

Untreated hepatitis $\mathrm{c}$ increases the risk of death in dialysis patients ${ }^{18}$. And poses a risk of spreading it to other patients as well as healthcare workers if infection control measures are not taken efficiently. Risk of acquiring hepatitis $\mathrm{c}$ infection is directly related to duration of dialysis .It has been proven in many studies $^{19-23}$.Our study results also endorsed the similar idea. In our study we divided the patients in three categories on the basis of duration of dialysis and results showed that $12 \%$ patients having dialysis less than 50 ,32\% patients having $50-100$ dialysis and $56 \%$ having more than 100 dialysis got HCV infection respectively. This suggests that many patients acquire infection from dialysis centre via horizontal transmission.

Horizontal transmission of hepatitis $\mathrm{c}$ is an important issue to date in Pakistani dialysis centres as compared to many parts of the world where it is negligible now because of timely diagnosis and management of hepatitis $\mathrm{c}$ as well as due to proper infection control measures.

Commonly used test to diagnose hepatitis $\mathrm{c}$ is either ELIZA or PCR. With ELIZA there is a possibility of false negative results in immunocompromised patients like on dialysis or recently infected patients and false positive results in previously treated patients making PCR for HCV RNA more reliable. In our study out of 152 haemodialysis patients, $94 \%$ cases were positive by both ELIZA and PCR methods while $6 \%$ cases were
ELIZA negative but PCR positive. Similarly in another study done in 112 haemodialysis patients 78 patients were tested negative for HCV antibodies by ELIZA. but in $22(28.2 \%)$ patients out of $78, \mathrm{HCV}$ RNA was detected by $\mathrm{PCR}^{24}$. So, we suggest screening of Dialysis patients with PCR before enrolment in dialysis centres and then at regular intervals afterwards.

In Pakistani population blood transfusion is another important source of hepatitis c infection because of poor screening in many blood banks ${ }^{25}$. Haemodialysis patient needs multiple blood transfusions as compared to general population making it one important factor responsible for hepatitis c infection in them ${ }^{19}$.

In our study we found that blood transfusions clearly increases the risk of hepatitis $\mathrm{c}$.out of 100 positive cases $67 \%$ had $>2$ transfusions per month,27 \% had 2-4 transfusions per month and $6 \%$ had more than 4 transfusions per month another study also showed that number of blood transfusion is directly related to hepatitis c infection in dialysis patients(10)it has been proven in many other studies as well.(19,23). Management of anaemia with adequate dialysis and adequate dose of iron and erythropoietin will reduce the need of blood transfusion indirectly reducing the possibility of viral transmission.

\section{CONCLUSION}

In centres where hepatitis-c is more prevalent, PCR for HCV RNA should be preferred over ELIZA method for early detection of $\mathrm{HCV}$ viral infection.

\section{ACKNOWLEDGEMENT}

We are grateful to Dr. Baber Amin, Chief Consultant/Research Coordinator DHQ Sheikhupura, for his persistent help and encouragement throughout the study. 


\section{ETHICAL APPROVAL}

The study was approved from Institutional Review Board of DHQ Hospital, Sheikhupura, Pakistan, in its meeting held on 10/09/2017.

\section{REFERENCES}

1. Mahmud HM, Siddiqui M, Bashir B, Ali SF, Baloch AA, Masroor M. Hemodialysis patients profile at Dow university of health sciences, Karachi. Pakistan. Pakistan J Med Sci. 2014;30(6):1327.

2. Blach S, Zeuzem S, Manns M, Altraif I, Duberg A-S, Muljono DH, et al. Global prevalence and genotype distribution of hepatitis $C$ virus infection in 2015: a modelling study. lancet Gastroenterol Hepatol. 2017;2(3):161-76.

3. Stanaway JD, Flaxman AD, Naghavi M, Fitzmaurice C, Vos T, Abubakar I, et al. The global burden of viral hepatitis from 1990 to 2013: findings from the Global Burden of Disease Study 2013. Lancet. 2016;388(10049):1081-8.

4. Majumdar A, Kitson MT, Roberts SK. Systematic review: current concepts and challenges for the direct-acting antiviral era in hepatitis C cirrhosis. Aliment Pharmacol Ther. 2016;43(12):1276-92.

5. Hajarizadeh B, Razavi-Shearer D, Merat S, Alavian SM, Malekzadeh R, Razavi H. Liver disease burden of hepatitis $\mathrm{C}$ virus infection in Iran and the potential impact of various treatment strategies on the disease burden. Hepat Mon. 2016;16(7).

6. Sharma SA, Feld JJ. Acute hepatitis C: management in the rapidly evolving world of HCV. Curr Gastroenterol Rep. 2014;16(2):371.

7. $\mathrm{Au} \mathrm{TH}$, Destache CJ, Vivekanandan R. Hepatitis C therapy: Looking toward interferon-sparing regimens. J Am Pharm Assoc. 2015;55(2):e72--e86.

8. Grebely J, Page K, Sacks-Davis R, van der Loeff MS, Rice TM, Bruneau J, et al. The effects of female sex, viral genotype, and IL28B genotype on spontaneous clearance of acute hepatitis $\mathrm{C}$ virus infection. Hepatology. 2014;59(1):109-20.

9. Al Kanaani Z, Mahmud S, Kouyoumjian SP, AbuRaddad LJ. The epidemiology of hepatitis $C$ virus in Pakistan: systematic review and meta-analyses. R Soc open Sci. 2018;5(4):180257.

10. Khan S, Attaullah S, Ali I, Ayaz S, Khan SN, Siraj S, et al. Rising burden of Hepatitis $\mathrm{C}$ Virus in hemodialysis patients. Virol J. 2011;8(1):438.

11. Le Pogam S, Le Chapois D, Christen R, Dubois F, Barin F, Goudeau A. Hepatitis C in a hemodialysis unit: molecular evidence for nosocomial transmission. J Clin Microbiol. 1998;36(10):3040-3.

12. Rostami Z, Nourbala MH, Alavian SM, Bieraghdar F, Jahani Y, Einollahi B. The impact of Hepatitis $\mathrm{C}$ virus infection on kidney transplantation outcomes: A systematic review of 18 observational studies: The impact of $\mathrm{HCV}$ on renal transplantation. Hepat Mon. 2011;11(4):247.

13. Elzouki A-NY, Gargoum HM, Habas EM, Rayani AA, Othman $M$, others. Impact of hepatitis $C$ infection on renal transplant patients: A single-center experience in Libya. Saudi J Kidney Dis Transplant. 2014;25(6):1315.
14. Medhi S, Potukuchi SK, Polipalli SK, Swargiary SS, Deka P, Choudhary A, et al. Diagnostic utility of hepatitis $\mathrm{C}$ virus core antigen in hemodialysis patients. Clin Biochem. 2008;41(7-8):447-52.

15. Rigopoulou EI, Stefanidis I, Liaskos C, Zervou EK, Rizos C, Mina P, et al. HCV-RNA qualitative assay based on transcription mediated amplification improves the detection of hepatitis $\mathrm{C}$ virus infection in patients on hemodialysis: results from five hemodialysis units in central Greece. J Clin Virol. 2005;34(1):81-5.

16. Khokhar N, Alam AY, Naz F, Mahmud SN. Risk factors for hepatitis $\mathrm{C}$ virus infection in patients on long-term hemodialysis. J Coll Physicians Surg Pak. 2005;15(6):326-8.

17. Shafiq ST, Haq R, Shafi T. Prevalence and rate of seroconversion of hepatitis $\mathrm{C}$ in hemodialysis patients. Proceeding Shaikh Zayed Postgr Med Inst. 2003;17(1):19-22.

18. Stehman-Breen CO, Emerson S, Gretch D, Johnson RJ. Risk of death among chronic dialysis patients infected with hepatitis C virus. Am J Kidney Dis. 1998;32(4):629-34.

19. Al-Jamal M, Al-Qudah A, Al-Shishi KF, Al-Sarayreh A, Al-Quraan L, others. Hepatitis C virus (HCV) infection in hemodialysis patients in the south of Jordan. Saudi J Kidney Dis Transplant. 2009;20(3):488.

20. Makhlough A, Jamshidi M, Mahdavi MR. Hepatitis $\mathrm{C}$ prevalence studied by polymerase chain reaction and serological methods in haemodialysis patients in Mazandaran, Iran. Singapore Med J. 2008;49(11):921.

21. Polenakovic M, Dzekova P, Sikole A, others. Hepatitis C in Dialysis patients. Contrib Sec Biol Med Sci. 2007;1:239-65.

22. Fissell RB, Bragg-Gresham JL, Woods JD, Jadoul M, Gillespie B, Hedderwick SA, et al. Patterns of hepatitis $\mathrm{C}$ prevalence and seroconversion in hemodialysis units from three continents: the DOPPS. Kidney Int. 2004;65(6):2335-42.

23. Sy T, Jamal MM. Epidemiology of hepatitis $C$ virus (HCV) infection. Int J Med Sci. 2006;3(2):41.

24. Caramelo C, Bartolomé J, Albalate M, de Sequera P, Navas S, Bermejillo T, et al. Undiagnosed hepatitis C virus infection in hemodialysis patients: value of HCV RNA and liver enzyme levels. Kidney Int. 1996;50(6):2027-31.

25. Waheed Y, Shafi T, Safi SZ, Qadri I. Hepatitis C virus in Pakistan: a systematic review of prevalence, genotypes and risk factors. World J Gastroenterol WJG. 2009;15(45):5647.

\section{AUTHOURS CONTRIBUTIONS}

YH: Concepts, Design, Literature Review

RA: Manuscript Writing, Data analysis

NM: Manuscript Writing, Statistical Analysis

ZF: Manuscript Review

SN: Data Collection

AM: Manuscript Review 